\title{
The Influence Of Private And Public Finance, Organisational And Environmental Variables On The Performance Of Beauty Salons In The Free State, South Africa: A Theoretical Perspective
}

Patient Rambe, Central University of Technology, South Africa Nosiphiwe Mpiti, Central University of Technology, South Africa

\begin{abstract}
Although small, micro and medium enterprises (SMMEs), such as hair salons, have harnessed a subtle combination of private and public funding to bankroll their business operations, literature on the performance of SMMEs in developing countries that often identifies finance as a major obstacle to the SMMEs' survival, tends to be uncritical about the nature and sources of funding. In view of the fragmented nature of the literature that examines the isolated influences of private and public funding on performance, it becomes difficult to unpack the combined influence of these different funding sources on the performance of emerging firms. The problem is compounded further by the existence of limited literature that focuses on the environmental and organisational variables that mediate the fundingperformance relationship in small emerging firms. This article considers a critical integrated approach that is located at the intersection of types of funding (private and public funding), mediating organisational and environmental factors and performance, in explaining the SMME performance, well aware that there is a potential for large firms to crowd out the growth opportunities of SMMEs and the insufficiency of the "wicked financial problem" in explicating the performance of such firms. The theoretical study adopts hair salons as a metaphor for an otherwise large, complex beauty and cosmetological industry in its exploration of the combined influence of private and public funding on the performance of SMMEs, with organisational and environmental concepts as mediating variables. The study deviates from mainstream studies that tend to accord significance solely to finance in SMME development and therefore, places financing, organisational and environmental variables as key variables in explaning successful business performance. The main contribution of this paper is a conceptual framework that is based on the view that financing-performance does not occur in vacuum, but is rather mediated by organisational (human resources, technological acquisition, staff training and education) and environmental (technology acquisition, firm location, competition) variables.
\end{abstract}

Keywords: Public vs. Private Financing; Firm Performance; Hair Solon

\section{INTRODUCTION}

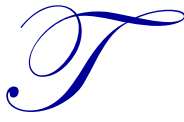

he socio-economic role of cosmetology services, such as hair salons cannot be taken for granted in South Africa, where aesthetic beauty and personal physical image have gained currency among all age groups and genders. As convivial places for reaching and engaging with diverse communities, beauty salons/ are considered "safe" spaces where individuals can focus on personal appearance, receive community news, and socialize (Linnan et al., 2014). The Public Health By-laws of the City of Johannesburg Metropolitan Municipality categorise hair salons or beauty salons under "hairdressing, beauty and cosmetology services". These services include: Shampooing and cleansing, conditioning and treating hair; chemical reformation of the hair that includes waving, relaxing and straightening; hair colouring such as tinting, dyeing and colouring by means of colour rinses, gels or mousses and lightening by tints, bleaches and highlights; hair cutting and shaping; barbering services such as shaving 
and singeing of hair; and the adding of natural and artificial hair and hair extensions (City of Johannesburg Metropolitan Municipality, 2004). An Annual Report compiled by the Skinwell Holdings Limited in 2011 considers hair salons as providing various products and services that include beauty treatments (including skin care clinical services) and hair, nail and body care enhancements (Skinwell Holdings Limited Annual Report, 2011). A "salon" therefore, describes a place where hairdressing service; cosmetology or beauty service; body piercing and tattooing; or massaging service are provided for private gain (City of Johannesburg Metropolitan Municipality, 2004). The terms beauty salons or salons are therefore adopted in this study to describe entities that engage in the above-noted socioeconomic activities in an effort to address the diverse nomenclature of beauty salons and avoid unnecessary ambiguity. Finally, it is important to underscore that hair salons are a sub-set of a rather expansive and burgeoning beauty and cosmetological sector.

The wide scope and scale of salon businesses implies that these business are most inclined to straddle survivalist firms and full scale enterprises. In fact, one perspective characterises small business entities, such as salons, as "small enterprises" operating in an informal sector, with a capacity to create job opportunities, contribute to economy-wide growth and generate tax revenues through a gradual process of formalisation (Davies \& Thurlow, 2009). Another perspective conceives such activities as low-productivity employment or "survivalist" strategies for poor households, which play a passive role in development and acts as a temporary substitute for social protection during the formal sector-led growth process (Davies \& Thurlow, 2009; Demacon Market Studies, 2010). A more nuanced perspective would conceive the activities of salons as located at the intersection of the formal enterprises and informal activities depending on the size, scale, level of formalisation and the asset base of the salon. This study therefore, renders hair salon businesses as an example of a rather large, complex beauty and cosmetological industry.

The enduring features of sustaining salons businesses, in spite of the size, scale and their nomenclature, are sufficient funding and a favourable funding formula for these entities. The major obstacles to small scale, micro and medium enterprises (SMMEs) growth and survival in South Africa has been lack of funding and access to business finance (Rogerson, 2008; Booyens, 2011). Salons, as part of SMMEs in the form of separate and distinct business entities that include co-operative enterprises and non-governmental organizations managed by one owner or manager (NCR, 2011:24), predominantly receive funding for their business start-up from manager/owners' personal savings, loans from friends and families (NCR, 2011). The reliance on personal funding is a consequence of limited access to bank credit due to nascent credit histories and lack of collateral to support the loans (Agwa-Ejon \& Mbohwa, 2015). However, although there is abundant literature on the funding constraints of SMMEs, the exact impact of each funding source, whether public or private, on SMME performance is often obscured by the indiscriminate treatment of the funding formulae in mainstream literature (see Sekolanyane, 2004; Pollution Prevention Grant Final Report 2007; Demacon Market Studies, 2010). Literature fails to differentiate the impact of private funding from public funding on organisational performance and sustainability. In other scenarios, the fragmented literature on funding of SMMEs seems to adopt an "either (e.g. public funding) or (private) perspective" (see Laosirihongthong et al., 2014; Linnan et al., 2014; Onsongo \& Muturi, 2015), thus neglecting possibilities for "double dipping" of SMMEs from both public and private funding sources. Nevertheless, the diversification of funding products and services has resulted in rich and complex choices for consumers, especially when compared to the early days of one-size-fits all with regard to working capital loans (Cohen and Nelson, 2011). The existing higher level of financial inclusion demands that SMMEs make prudent choices about the combinations of funding, financial products and services. Hence, the need to investigate the combined influence of private and public funding on the performance of SMMEs, especially hair salons.

The rest of this theoretical article focuses on; the research background and problem statement, the research questions, a detailed literature review, the supporting hypotheses, the methodology, an evaluation of the study's contribution and implciations, and the study's conclusion.

\subsection{Problem Background}

Much of the literature on funding for SMMEs considers funding sources as "either (public) "or" (private) funding scenarios and fail to adequately acknowledge the possibilities of consolidating public and private funding combinations (see Dieden, 2007; Demacon Market Studies, 2010; Perks \&Austin, 2013; Fredericks, 2014). Demacon Market Studies (2010) note that private funding provides safe havens for business operations-banks provide spaces to 
save money, financial support for business ventures and advice on how to run the finances of a business. While the study explores in greater depth the role of these financial institutions on the funding and growth of hair salon businesses, public funding is given little attention. For instance, although lack of government support is highlighted as an impediment to the local growth of hair salons, the nature of such support, be it financial or business skills, is never clarified.

In addition, Fredericks (2014) foregrounds the centrality of public financing, such as that provided by the Department of Trade and Industry project, the South African Women's Entrepreneur Network (Sawen), in expanding financially but is silent about private funding, thus sustaining the polarity of funding mechanisms. This in essence, then, fails to affirm the desirability of private and public financing in improving performance of small, micro and medium enterprises (Cecchetti \& Kharroubi, 2012). Dieden's (2007) study that examines the link between the boom of SMMEs and the existence of electricity and telephone infrastructure, notes that the impact of SMMEs on economic development hinges on public finance provision, capacity building and the coordination of efforts between government institutions. The study however ignores the role of private funding and thus creates a fictitious dichotomy between public and private funding and elides the possibilities of integrating these funding sources. Beck and Demirguc-Kunt (2006) claim that the lack of equity capital investments in Afro hair salons makes these businesses more dependent on sources such as bank lending and other types of financial support (Beck \& Demirguc-Kunt, 2006). Hence, although there is a demonstrable value of financial resources for salons operations, the ambiguity of equity capital with regard to its sources makes it open to varied interpretations.

Salon and SMME studies that distinguish private from public funding, and those that consider their combinations confine their focus to particular aspects of performance and in that way downplay the complexity of performance (Rogerson, 2006; Oni \& Daniya, 2012). Tengeh et al. (2011) observed, in their research into the pathways that African immigrants adopt to finance and start up their new ventures such hair salons that, personal savings and borrowings from family members proved instrumental to the creation and sustenance of new hair salon ventures. The study indeed differentiates private from public funding by emphasising that personal savings $(61,2 \%)$, borrowing from friends $(97$, $8 \%)$, borrowing from co-ethnics $(83,7 \%)$ and from self-help financial associations were more dominant than funding from banks and other public funding. However, this study examines hair salons as a metaphor for a complex hairdressing, beauty and cosmetology service industry.

Public funding is of significance in this sector. Perks and Austin's (2013) study on the business growth opportunities and strategic planning of hair salons in South Africa acknowledges the significance of external funding to business expansion. Their reference to business performance is evident in their claim that hair salon businesses do not actively engage in strategic planning for business growth nor regard a business plan as essential to business growth. Although this study is informative in its articulation of the strategic orientation of hair salon businesses, it is insufficient for understanding funding sources as they relate to various components of performance such as firm profitability, return on investment and economic sustainability. There also exists literature, such as Rogerson (2006), the National Credit Regulator (2011), The International Organization of Securities Commissions (2014), which disaggregates diverse sources of private and public funding, which, examine SMMEs in general and not hair salons in particular. As such, the social circumstances of hair salons, such as their one man/women orientation, their dependence on external customer base and susceptibility to business rivalry, increase their vulnerability with regards external funding even though their survival is assured by the receipt of public funding.

Financial literacy is also a formidable step towards leveraging the financial inclusion of clients. Cohen and Nelson (2011) and Kwaning, Nyantakyi and Kyereh (2015) in their studies attempt to disaggregate funding sources by arguing that financial capability, the ability and opportunity to use the knowledge and skills implied in financial literacy, are tied to the education of the consumer, in the case of this study, a salon manager or owner, and those that sell financial products such as government institutions banks, small credit institutions. They also note that although consumers such as salon managers/owners may have financial prudence in familiar environments where a majority of financial transactions occur informally, with increased access to more service providers and more products in more complex, dynamic financial landscapes, such financial managers are nevertheless confronted with financial options that are beyond their comprehension. 


\subsection{Problem Statement}

Effective access and use of funding, which triggers improved performance of SMMEs, is often hampered by: asymmetries of information and power between financial institutions and poor consumers (e.g. SMME managers/owners); an imbalance between inexperienced customers and more sophisticated financial products or services leading to ill-informed customer decisions; and institutional abuses (Cohen \& Nelson, 2011; Thusong Service Centre, 2016). Well informed salon managers/owners' decisions about funding, therefore, necessitate their knowledge of all funding options available and how such different financing formulae impact on their business performance and economic sustainability. Yet the literature that considers the funding of SMMEs by government and micro financial institutions tends to focus on SMMEs startup and development rather than SMME performance and long term sustainability (Oni \& Daniya, 2012). Literature that directly links poor private and public financing to firm performance is, nevertheless, hard to encounter (Fafchamps \& Schundeln, 2013). The irony is that the fragmented extant literature which covers business performance indicators of salons, such as growth opportunities on the African context, seem to neglect the role of funding as their focus of investigation (Perks \& Austin, 2013; Onsongo \& Muturi, 2015). The problem, therefore, is the paucity of research into the combined influence of public and private funding on the performance and sustainability of SMMEs, including the associated mediating organisational and environmental variables. It would, however, be naïve to conceive the private/public finance-performance-sustainability as operating in a vacuum, as other selected variables that mediate this relationship should be factored in to provide a more authentic, integrated framework to understanding the funding-performance-long term sustainability relationship.

\subsection{Research Questions}

The above-mentioned problem statement is considered in relation to the following research questions that inform this study:

1. What is the contribution of public and private funding to the performance of hair salon businesses in the Free State Province, South Africa?

2. How important is the mediating role of organisational and environmental variables in the fundingperformance of hair salon business relationship?

3. To what extent does the combined influence of private and public funding, organisational and environmental variables impact the performance of hair salon businesses?

\section{LITERATURE REVIEW AND SUPPORTING HYPOTHESES}

\subsection{Public Funding}

Public finance is defined as a field of economics concerned with how a government raises money, the way in which that money is spent on the provision of publicly desirable services, how it secures the financial resources to pay for these services, and the effects of such provision on the economy and society (Kareem \& Krishnan, 2011). The importance of public financing lies in the way it complements and assist small businesses, particularly those, such as beauty salons, which do not have access to private funding from banks and micro lending institutions. As literature suggests, some of the main barriers to private financing of SMMEs, such as beauty salons, include lack of steady income flows, insufficient collateral to support loan applications, high transaction costs and unstable income which makes it too risky to lend money to the SMME owners (Nawai \& Shariff, 2010:152). The lack of financial resources can be a serious obstacle to Afro hair salons development (Maurel, 2008:18). This view is buttressed by a growing body of research (see Chandra's 2001; Fatoki \& Garwe, 2010; Sobeková Solík \& Sipko, 2014; Rizos, 2015) which found out that public funding sources, such as government agencies, church and community groups, contribute far less (about 5\%) of SMME funding in comparison to private savings, family savings, individual savings, and retained earnings from a previous business (private sources of funding).

The public funding discourse is disjointed and does not consider the different public funding institutions operating in the South African context. There are a number of support programmes that the South African Department of Trade and Industry (DTI) has identified and implemented, as part of the public funding programmes and these include the 
Khula Enterprise Development Fund (Khula), National Youth Development Agency (NYDA), Small Enterprise Development Agency (Seda) and the Tsumisano Trust (NCR, 2011). Although the funding from these agencies are conceivably meagre, when compared to private funding opportunities, these public agencies remain one of the fundamental pillars of the funding formulae of SMMEs, such as hair salons, in the country. The small and fragmented funding of hair salons in South Africa should, however, be noted against the backdrop of foreign migrants' domination of this sector, and how these agencies tend to be too risk averse such that they impose stringent lending measures.

The Khula Enterprise was established to render financial assistance to small to medium sized business manager/owners who wanted start or expand their businesses but did not have enough collateral or security to support the loans secured from banks (NCR, 2011:38). These business managers or owners approach Khula to help them develop business plans and facilitate the credit application process. As a component of its lending criteria, Khula has partnered with South African financial institutions such as ABSA, Standard Bank, Nedbank and First National Bank and the Khula financial scheme for credit indemnity (NCR, 2011:38). These financial institutions evaluate the entrepreneurs' business plans, facilitate the application using their respective lending criteria, approach Khula for indemnity cover upon the loan's approval and assign a mentor who will assist the novice entrepreneur in the execution of the business plan and setting up of the business (NCR, 2011:39). Khula is, therefore, the bona fide guarantor to registered commercial banks and financial institutions that bankroll the SMME sector (Mutezo, 2005:43). This significant role that Khula plays is indeed underscored by Rwigema and Venter (2004:396) in their statement that: "The guarantees serve as collateral for SMMEs, and are based on a risk sharing arrangement, whereby Khula assumes a portion of the risk associated with lending to the SMME sector."

The Small Enterprise Development Agency (SEDA) is another public funding institution that is at the disposal of SMMEs. This institution renders a well-organized and effective promotion and supports SMMEs in order to promote economic growth and socio-economic development in South Africa (Mutezo, 2005:44). The bulk of the post-apartheid SMMEs support programmes have however, targeted small and micro enterprises, while neglecting the informal economy (see Rogerson 2006), in which most of the unregistered hair salons operate. As a result, most of these informal enterprises do not have access to public funding. More so, the fact that the bulk of these operators are foreign immigrants, means that access to these loans may be constrained by the risk aversive behaviour of these institutions and these immigrants' lack of knowledge of these institutions.

The Industrial Development Corporation (IDC) is also another public lending institution that offers its services to the SMME sector. Ntsika (2002:129) states that the IDC is a self-financing national development and finance institution. Its main mandate is to contribute to the economic growth of South African enterprises and to empower the South African previously disadvantaged population. The institution runs multiple funding options for SMMEs such as equity investments, commercial loans and quasi-equity (Ntsika, 2002:129). The geographical dispersion of IDC Offices across various regions in South African implies that SMMEs, such as hair salons, are inclined to have easy access to these offices. It should, however, be stated that the inordinate bureaucratic complexities, stringent lending mechanisms and the various application documentation that is required may militate against small hair salons' attempts at accessing the available funding opportunities and benefits. Therefore, availability of funding may not always translate into accessibility and ultimate approval of funding opportunities to the less fortunate managers owners of salons. In view of the foregoing discussion it can be postulated that: Public funding sources contribute comparatively less to hair salon business development (especially the dominant foreign-owned ones) compared to private funding.

\subsubsection{Relationship between Public Funding and Performance of SMMEs}

The relationship between financial resources and performance is mediated by expansion strategies and moderated by growth and expansion (Mahasi et al. 2013: 451). Mahasi et al (2013), also state that there is a direct relationship between a firm's resources and the firm's performance. A study conducted by Oni and Daniya (2012) on the role of Nigerian government financial institutions in promoting the development of SMMEs shows a close connection between funding and the growth of these enterprises. Although financial resources availed by the government need replenishment, such resources serve as an economic lubricant that facilitate the rapid development of Small and Medium Scale Enterprises. Lack of public funding is, however, viewed as one of the reasons for the faltering of business operations, such as hair salons (Perks \& Austion, 2013; Jiang, Zhiming, \& Chanyan, 2014; Kwaning, 
Nyantakyi \& Kyereh, 2015). The low performance of some hair salon startups, especially those owned by foreigners, can be attributed to complicated public funding mechanisms owing to the government's reluctance to fund foreigned busineses, which dominate the hair salon industry. In addition, government reluctance arises from these business operations' risk averseness behaviour, lack of collateral security, lack of proper financial management records and the sheer size of these businesses, which compromise the prospects of profitability. Therefore, ceteris paribus (i.e. controlling for other variables) publicly funded hair salon SMMEs would be expected to perform financially lower than privately funded ones. Consistent with this understanding, this study postulates that: Public funding contributes considerably lower to the performance of hair salon businesses (especially foreign-owned ones) compared to private funding.

\subsection{Private Funding}

Private financing is the support received from commercial banks, retail banks, financial credit schemes, micro lending institutions, personal savings, borrowing from family and friends, individual lending schemes (matshonisas) and community and collective savings (stokvels). The commercial banking sector is the main source of external financing for SMMEs such as hair salons and it is important for the banks to provide finance to the SMME. Although banks perceive SMMEs, such as hair salons, as an attractive line of business and have developed effective monitoring systems (NCR, 2011:44), the risks of "smallness" tend to discourage national banks from funding hair salons. The first challenge of smallness that constrains access to sustained credit schemes from financial institutions, such as banks, is their lack of steady and regular income (Nawai \& Shariff, 2010:152). The second challenge is that banks are reluctant to lend those small enterprises owing to their short banking history and ambivalent credit record and rating. The third challenge is that most small enterprises are unable to provide financial statements to back up their business performance claims (Pandula, 2011:258; Kwaning, Nyantakyi \& Kyereh, 2015). The last challenge is that most hair salons evade paying taxes due to their survivalist orientation and do not have comprehensive and logical business plans.

Literature often highlights that the financing for SMMEs, such as salons, is severely undermined by lack of collateral security. The provision of financial facilities such as short term personal loans, long term home loans, car loans and large overdrafts often require some form of debt financing and hence they require collateral (Mutezo, 2005:45, Freeman, 2015). Collateral describes the physical assets (equipment, land, buildings, personal assets such as house or car) that the borrower possesses which can be disposed by the financial institution to recoup the loan's principal and interest should the borrower defaults payment completely.

Micro financing: "Microfinance" refers to the provision of formal financial services and credit to poor and low-income people and the non-salaried, as well as others systematically excluded from the financial system (Consultative Group to Assist the Poor (CGAP), 2012). The sources of micro finance include Matshonisas (i.e. informal, unauthorised money lending individuals), non-governmental organisation (NGO's), micro lenders and community or group savings (stokvels), which are outlined in the subsequent sections of this study.

Matshonisa: There are "loan sharks" and lenders who predominantly operate in the townships in an informal manner. "Matshonisa" means making you poorer and is a reference to the interest payments attached to their loans or to the debt trap into which the borrowers often fall" (Rwigema \& Venter, 2004:394. The loans offered by these lenders are often as high as double or three times the principal lent. Although, these individuals are renowned for lending, they are often not the preferred lending options for many salons due to their ruthless tactics in cases where borrowers default payments or take long to pay back.

Non-governmental organisations ( $N G O s$ ): They serve as subsidiaries or intermediaries of donor institutions and offer a limited range of products (Mutezo, 2005; Bromideh, 2011). The low visibility and the often obscure marketing strategies of these institutions may mean that the small enterprises, such as salons, which are mostly characterised by imperfect information due to their limited access to diverse forms of media, may be oblivious of these institutions. Based on this view, we are of the opinion that few hair salons get limited funding from NGOs, thus compeling them to secure funding from micro lenders, community-based organisations, friends or their personal savings to start-up their enterprises. 
Micro lenders: They only provide small loans and do not require collateral for the loans provided as well as focus on the personal short-term loans that working people make. They often require Identification Documents (ID) and proof of monthly earnings from the loan applicants, which they use as security and compliment by a credit record that is checked through the national systems (Mutezo, 2005:47; Johannsmeier, 2007). Typical examples of microenterprise lenders operating in South Africa include Small Enterprise Foundation, Akanani Financial Services, Phakamani Financial Services, Ikusassa and Mazwe (Bank Seta, 2013). Nevertheless, the microenterprise lending sector remains underdeveloped due to a variety of reasons such as labour intensive methodologies for microenterprise lending, requirements of an up-front investment to establish an institution and reach scale, restricted access to on-lending capital and a serious shortage of experienced and capable executives and policy makers in the sector (Bank Seta, 2013).

Community or Group Savings: The most dependable and cheap form of funding for most SMMEs is community or group saving. These groups savings are colloquially called "stokvels" or "rounds" as group or community members contribute some monthly instalments, which all members have consecutive access to weekly or monthly. The term "stokvels" is a derivative of the term "stock fair," which described the livestock auctions conducted by English settlers in the 19th century (Calvin \& Coetzee 2010), but now speaks to the social spaces for collective engagement, sharing and generation of mutual support. Since stokvel members enjoy considerable latitude in their investment options from their group contributions, we postulate that these individual members can direct their funds to the replenishment of their small businesses. Mutezo (2005) and the Invested Development (ID) (2012) clearly note the cost-effectiveness and convenience of group savings which lies in the equal opportunities for all members to a pool of funds monthly at minimal cost that they can use to buy equipment or finance their enterprises. Although there is no interest on the principal contributed, the saviness of these contributions include the absence of bank charges and collection fees and the lump sum pay-outs accrued to the one whose turn it would be to receive the collective savings. There are an estimated 421000 stokvels in South Africa, constituted by a total 8.6 million stokvel members, which represents $23 \%$ of the adult population (Ipsos, 2014). Ipsos (2014) estimates that the robust traditional collective saving (stokvels) market is worth R25 billion. We need to exercise caution in assuming that all this figure is directed at SMMEs, let alone hair salons, as the individual contributions are normally not subtantial amounts, and are spread over a large landscape of individual and group commitments. The stokvel contributions are nevertheless, directed at personal savings, birthdays, burials, groceries and investments just to make a few (African response, 2012).

In view of the foregoing discussion on the diversity of private funding sources and their phenomenal advantages compared to public funding it can be assumed that: Private funding contributes more to hair salon business development compared to public funding.

\subsubsection{The Relationship between Private Funding and Performance of SMMEs}

Although studies have stated that funding/finance may have positive influence on the performance of the enterprise (Zhenxing \& Zheng, 2008; Evgeny, 2015) the exact relationship between private funding and performance remains unclear and ambiguous. Scholars such as, Zhenxing and Zheng (2008:142), Kouser, Bano, Azeem and Hassan (2012), and Niresh and Velnampy (2014) hypothesize that there is a direct positive relationship between an enterprise's profitability and firm performance. We postulate that profitability derives from a strong asset base and is itself leveraged by private funding capabilities. This consummates the shared view that a unique set of internal resources, with internal funding as a component, and capabilities of small firms are fundamental in determining its strategies and eventually performance (Tvedten et al., 2014). It can also be hypothesized that optimal performance of hair salons is dependent on the strong funding capabilities of such firms as financing underpins access to the hair salon business equipment such as dryers, blowers, straighteners, computers and telephones, as well as chemicals, dyes and remuneration of personnel. The flipside is also plausible, for, although accessing private funding may be the bedrock for commencing business operations for hair salons, the long term sustainability of such firms hinges on other considerations, frugal spending, management capabilities and strategic orientations of the firms without which financial resources can be put to waste. Therefore, the above provides evidence to support the claim that: There is a positive relationship between private funding and the performance of hair salon businesses. 


\subsection{Internal Intervening Variables}

\subsubsection{Human Resource Base and Organisational Performance}

The relationship between public and private sources of funding and performance is mediated by organisational and environmental variables. Organisational variables are those resources, skills and capacities which the organisational has full control of and which when converted into competencies and capabilities may generate optimal performance for the company and for its external stakeholders. These variables include the human resource base, staff training and educational attainments of the staff complement. The adoption of formal human resources practices in an enterprise has an influence on the firm performance (Rambe, Mupani \& Chipunza, In press) and small firms are no exception. The study by Ojokuku et al. (2014) on the interplay between HRM practices and the performance of Nigerian SMMEs reported that HRM practices have a significant impact on business performance $(\mathrm{F}(4,66)=18.569 ; \mathrm{R} 2=0.529$; $\mathrm{P}$ $<.01)$ and that HRM practices contribute reasonably (52.96\%) to business performance. As a result, we are of the view that:

H1: There is a positive relationship between human resource base and the organisational performance of hair salon SMMEs.

\subsubsection{Staff Training, Educational Attainments and SMME Performance}

The training of staff and academic credentials should be perceived in relation with their potential to shape and influence the productive potential of SMMEs. Organisational training and academic qualifications unquestionably mold and channel the value systems and mental dispositions of SMME managers in line with the vision, mission and values of the organisation. An empirical research conducted by Katou and Budhwar (2010) into 178 organisations operating in the Greek manufacturing sector revealed that employee skills, attitudes and behavior had an impact on performance. By the same token, the possession of skills and appropriate attitudes can be traced back to the appropriateness of the training opportunities and educational attainments of SMMEs managers/owners. A handful of other studies (Rambe, Mupani \& Chipunza, in press; David \& Luiz, 2015) also indicated that HRM practices, such as training and development, and the job-qualification mix, have an effect on a firm's bottom-line performance. Training (organizational variable) helps the employees to encourage self growth and the enterprise's growth, just as training plays an important role in improving the firms' performance and inreases productivity (Dabale et al., 2014:66). Therefore, it can be postulated, drawing on the above literature that: There is a positive relationship among staff training, educational attainments of hair salon staff and the performance of their busineses.

\subsection{External Intervening Variables}

\subsubsection{Technological Acquisition and Performance}

Technology acquisition involves bringing in new technology from external sources rather than using the firms' own internal research and development activities (Mortara \& Ford, 2012). Mortara and Ford (2012) state further that specialist technical expertise and capabilities are often difficult to obtain and thus a firm may not have the ability or wish to commit resources in order to develop technology internally. Therefore, bringing in new technologies can provide an enterprise with the opportunity to develop new products and enter new markets. Technology acquisition (organisational variable) has a huge influence on the employee performance and it is considered the most important factor in influencing the improvement of a firm's performance (Imran et al., 2014:59). This view is, however, not necessarily universal as there is evidence to the contrary. For instance, Tsai and Whang's (2008) study on the influence of external technology acquisition on firm performance, reveal that although there is a positive impact of external technology acquisition in that a firm performance increases with the level of internal R\&D efforts, external technology acquisition does not provide a significant contribution to a firm's performance per se. The initial acquisition of sophisticated technology may cost a cash strapped hair salon in the short term and threaten its survival, but the savings derived from reduced overheads owing to technology adoption may contribute to profitability, growth and long term economic sustainability of these previously labour intensive salons. Our assumption is that if a salon can survive the initial sunk costs of technology acquisition by scaling up production and overcoming competition, its performance 
can be optimised in the short to medium term. Therefore, we postulate that: There is a positive relationship between a firm's technological acquisition and its financial performance.

\subsection{Environmental Factors}

Retail and Personal Services Training Council (RAPS, 2015) states that competition for clients is high among hair salons in South Africa in general and particulartly in smaller cities, such as Bloemfontein. The industry tends to operate with a fair degree of price-based competition, resulting in a high rate of salon closure as rivals slash prices to attract reluctant customers in ways that result in the business only breaking even or suffering severe losses as it fails to recoup costs. More professional operators concentrate on providing high quality hair, beauty and cosmetological services, in that way yielding high levels of customer fulfilment and repeated visits compared to overrelying on attracting clients through low pricing only. The RAPS Report (2015) states further that the main basis of competition between hairdressers is their marketing strategies, such as fair pricing of services, monthend promotions, discounts and delayed payment terms to regular customers, entertainment facilities (e.g. showing programmes on popular TV channels, and provison of entertainment to kids), and the use of sales agents to approach customers from a distance and directing them to the business premises. The industry comprises of small enterprises, due to low entry barriers but fair and competent pricing shapes business survival.

The location of a hair salon business has an influence on its level of exposure, frequency of visits and convenience to the customers and ultimately the business' income flow. There is convergence of literature on the view that, in locating a hair salon business, the owner must consider the population of the area, potential customers of the business, the accessibility and visibility of the business, the zoning of the location and future planning of that location area, the competition levels exerted by other businesses in proximity to the hair salon, the location costs, personal factors, rentals and other special considerations, such as special requirements, parking lot, crime rate and governmental restrictions and laws (Barnard et al., 2011; Mmari, 2015; RAPS, 2015).

There is consensus of opinion on customer care being the bedrock of improving the effectiveness of the business operations (Barnard et al., 2011; Suttapong \& Tian, 2012). The enterprise should be oriented towards the customer to understand their needs, determine their satisfaction levels and improve their business processes, as well as satisfy and exceed their desires and aspirations. Although market-oriented industries and enterprises survive and collapse, depending on the levels of satisfaction of their customers, businesses should regard customer satisfaction as their strategic bottomline (Centre for The Study of Social Policy, 2007; Suttapong \& Tian, 2012). Extensive efforts, should be made in the hairdressing industry to gauge customer expectations and reactions to services in a continuous effort to improve, build on and expand their market share. If hairdressing businesses' customers are content with their services, the use of their products and services will increase, thereby increasing their chances of profitability.

The marketing strategies of hair salons must trascend fair and affordable pricing to include the promotion of the good name and image of the business. This can be achieved through: the hairdressers' keeness to provide a free, better quality service in the event of apparent service failure, use of new and innovative hair styles as a marketing tool, and the hairdressers' willingness to extend working hours and opening during weekends to service busy customers who are unavailable during work hours. Hair salons depend on referrrals, word of mouth, and informal information networks for the exposure and visibility of their business activities, thus monthend specials, discounts and free services, such as re-doing hair and hair wash for frequent high paying customers, can form an integral part of their offering. The above discussion, therefore, enables us to assume that: There is a positive relationship between the environmental factors and firm performance.

\subsection{Firm's Performance}

Firm performance for hair salon businesses, implies delivering sustained, superior returns to the owners (i.e. profitability), increased provision of quality services (i.e service growth) and outperforming competitors consistently, while satisfying the needs of the stakeholders (Mahasi at el., 2013:453). Mahasi at el. (2013) also argue that performance has multiple meanings depending on the discipline and that it is a function of controllable or strategic variables and non-controllable or environmental variables. However, Naude (2007:3), Agbobli (2013), Rambe and 
Makhalemele (2015) state that an organisation's performance relates with the effectiveness with which it carries out the tasks and activities to be performed in the process of providing products and services.

In many studies in the field of strategic entrepreneurship, firm performance is defined as a dependent variable and the entrepreneurship activity of the firm is considered an independent variable. There is strong agreement among the researchers that successful entrepreneurial activities, such as creating new products, processes and markets, positively correlate with the improvements of a company's performance (Mohutsiwa, 2012:45, Rambe, Ndofirepi and Dzansi, 2015, Ndofirepi, 2016). An enterprise's success or level of business performance can be measured by its growth in terms of sales turnover, profits, rates of return on investment, product or service expansion, productivity, as well as decreases in costs and its employment turnover rate (Jacobs, 2011).

The relationship between financial resources and performance is affected by expansion strategies and moderated by growth and expansion (Mahasi et al., 2013: 451). The authors also stated that there is a direct relationship between firm resources and firm's performance, because resources enable the firm to: expand its productive capacities, extend its market share through appropriate marketing strategies and identify the appropriate human capital critical to the provision of high quality, sustainable services.

\section{PECKING ORDER THEORY (POT)}

Since public and private funding form an intergral part this paper, a theoretical approach rooted in the significance of funding in business performance provides a useful interpretive and analytical lens to this investigation. Aabi (2014) indicates that information asymmetries between a company (SMMEs) and its financial partners are responsible for the existence of a pecking order in the financing of the company. As such, the Theory of Pecking Order postulates that financial resourcing unfolds in a context of asymmetric information and this increases the cost of financing the business through means such as debt, borrowing and equity. The theory assumes that firms are confronted with competing tradeoffs when it comes to choices of funding (be it public or private, internal or external), thus leading to the creation and enforcement of a perking order. A company should rather focus on internal sources of financing before resorting to external financing or investors to the company (Aabi, 2014) due to the relative ease and lower cost with which internal funds (personal loans from relatives, friends) can be generated compared to external sources.

More so, the company must follow a hierarchy of financing controlled by the need for external funds. In most cases, financing by internal funds should be promoted instead of financing by external funds, according to the following hierarchy: cash flow/debt/issue of shares (Myers \& Majluf, 1984; Aabi, 2014). If small firms, such as hair salons subscribe to the Theory of the Pecking Order, it would be mandatory for them to justify their choices of public and private funding. The consequence of such justification would be a hierarchy of funding models, driven by the varying cost of each funding structure, its associated risks and perceived convenience. The Pecking Order theory, therefore, compels business leaders to decide on funding options based on their risk averseness compared to their daring personalities to maximize their shareholder's wealth or to act in their own interest. In both cases, the business owner/manager acts to maximize the benefit of certain members of the company (Aabi, 2014).

\section{METHODOLOGY}

This paper adopts a theoretical stance. A theoretical research "aims to increase the understanding of phenomena and the relationships among key components of phenomena and to accomplish these goals, researchers considers the relationships among various aspects of the phenomena, and the relevant external factors" (Van Scotter \& Culligan, 2003). The existence of a lack of systematic research rigor in considering public and private sources of funding in relation to business performance influenced the current study, which examines the combined influence of public and private funding and other mediating organisational and enviromental variables on the performance of hair salon businesses in South Africa, and in particular the city of Bloemfontein, the Free State Province. The current research, therefore, considers the disparate literature on public and private funding, environmental factors and internal capacities of SMMEs as well as performance, in its examination each of these issues with a view to developing a conceptual framework on performance and long term sustainability of SMMEs. 


\subsection{Observation and Discussion}

The study acknowledged the dominance of the foreign immigrants in the beauty salon and cosmetological services sector and the marginal participation of South African citizens in this sector. It seems this dominance of economic immigrants in the sector partly explains the reluctance of large banks and public funding institutions to support this sector, their stringent public funding policies and the limited public funding opportunities available to these SMME manager/owners. As Tengeh et al. (2011) rightly observe, African immigrants who start up or operate small businesses are more disadvantaged than their local counterparts with regard to accessing capital from formal financial institutions and hence their resorting to personal savings, small business credit, family credit, and loans from informal financial institutions.

Consistent with the Pecking Order theory, hair salons,especially the foreign-owned ones, are compelled to internally source and augment their finances to mitigate the excessive costs of borrowing, such as high interests and short grace periods for repayments. Combinations of personal savings, borrowing from friends and community saving can ameliorate the pressure to approach local banks and NYDA, which are least likely to support their ventures due to their perceived discriminatory practices. The Perking Theory resonates with Fatoki's (2014) claim that firm life-cycle theory suggests that SMMEs should start operations with their internal equity before moving to other sources of finance to internalize risk and reduce the cost of borrowing at the nascent and fragile stage of the business.

Systemic blockages are also prevalent in the public funding of SMMEs, such as hair salons. Onio and Daniya's (2012) study on public funding in Nigeria, observes that many public funding policies designed for pro-poor SMME funding have no benefits for these intended beneficiaries because of various reasons that include: complex administration of loans, poor financing of credit schemes and concentration of services designed to support rural poor SMMEs in urban areas. Perhaps such stringent lending policies applied by both public institutions and large private institutions explain the heavy dependence of hair salons on private and personal funding from private savings, Matshonisas, friends and relatives and small organisations such as small private lenders and non-governmental organisations. The diverse and yet small and fragmented funding sources could complicate the startup of new ventures, as huge capital outlays may be required and these are often beyond the reach of these small funding sources or the paying capacity of these managers/owners. Nevertheless, the internalisation of risk evidenced by hair salons' dependence on internal funding sources is consistent with the Perking Theory's acknowledgement of trade offs that underline the small businesses' adoption of different funding models, be they private or public, short term or long term borrowing.

The current study also articulated the role of other institutional factors, such as the availability of highly motivated and skilled human resources personnel without which the public or private financing will not even make hair salons break even. Formal human resource practices such as objective recruitment of highly qualified staff and their knowledge base all shape their successful accomplishment of tasks, which invariably impact performance. Mahapatro (2010) highlights that the adoption of best employee resourcing strategies in the competitive contemporary business world has a competitive advantage, which can bring about increased organizational performance. However, the challenge for most survivalist hair salons is their informal recruitment practices, which are characterised by the appointment of relatives, friends and acquaintances, the lack of established formal appraisal systems and indecent payment structures, all of which undermine their long term profitability and economic sustainability. However, these HRM practices vary depending on the size, location and clientele targets of the beauty salons. Large upmarket hair salons located in posh suburbs are more inclined to have formalized HRM practices and render lucrative rewards than small survivalist hair salons located in down town Bloemfontein that target low income customers. Hair salons, therefore, have a narrow choice to make as human resourcing is an inevitable cost for the firm which also affects the firm's performance. Consistent with Perking Order Theory, they may save costs by internallly bankrolling their informal/quasi-formal recruitment practices and compromise the quality of their services or they may bear the brunt of private financing through banking institutions or other money lending institutions but face prospects of better quality services, service growth and profitablity. They can also partner with local citizens/businesses who can assess banks and government institutions on their behalf (some subtle form of fronting).

Although hair salon activities such as plaiting of hair, weaving, pedicure and manicure may not require sophisticated knowledge of cosmetology, other related activities require considerable mastery. These activities include facial skin 
care through chemical deposits, electrical or mechanical means, tattooing for cosmetic purposes; body bronzing by means of ultraviolet radiation or any similar method that may need more sophisticated knowledge and skills (City of Johannesburg Metropolitan Municipality Public Health By-laws, 2004; Dzansi \& Amoakoh, 2014). Therefore, both background training and continual on-the-job training are critical to improved specialised skills and job performance. Imran et al. (2014) affirm that bridging the gaps between the novice employees and their high skilled superiors through training contributes directly to decision making and the consequences of such decision making. Thus, salons should implement training in their enterprises so that they can improve their employee's skills and knowledge. While parnership with local hair salon businesses may offer a stop-gap measure to foreign-business owners to access the necessary training offered by private banks and government funding agencies, such as NYDA, securing South African citizenship/permanent residence status may be a long term solution to their public funding woes. In fact the NYDA documents numerous naratives in which they state the benefits of the managerial, technological and accounting management support offered to new start ups and existing small businesses (see NYDA website).

Although the level of technological sophistication and mechanization of hair salons may contribute to high sunk costs that may reduce marginal profits of the business in the short term, the reduced overheads (due to reduced labour employment) per unit may increase the profitability of the firm in the long term. At the basic level, all formalized hair salons employ some rudimentary technologies such as blowers, dryers, computers, hair clips and basic hair chemicals. It can be argued that, although higher firm performance is tied to advanced training in and improved abilities to use sophisticated technologies (Farooq \& Khan, 2011), which many of the survivalist beauty salons often do not have, their financial success lies in their capacity to invest in research and development related to state-of-the-art technologies. This is because the adoption of the latest technology (in sectors which seem to be giving similar products), may give a beauty salon an edge over its rivals.

\subsection{Proposed Conceptual Framework}

As already argued, literature has often considered private and public funding separately in the analysis of how both relate to firm performance. The study also demonstrated the ambiguity of studies that have failed to distinguish between private and public funding as they relate to performance. Such ambivalences about the private and public funding is demonstrated in Harash et al.'s (2014) blanket statement that financial access is very critical for a firm's growth and development and that the availability of finance has a positive influence on the development and growth of any enterprise (Harash et al., 2014:162). This, however, does not state clearly the type of financing that positively impacts on performance. The same applies to the shared claim that finance is the engine to improving the performance of an enterprise (Noor, Shariff \& Peou, 2008; Shariff et al. 2010). In our study we demonstrated how private financing seems to have more dominance on hair salon performance because of the easy access and diversity of private funding sources that include personal savings, private borrowing from friends and relatives, private money lenders, Matshonisas, and banks, compared to public funding institutions. We have also indicated that since economic migrants tend to dominate this sector, access to public funding tends to be restricted than private funding due to the risk averseness of public lending institutions and private banks.

The current study, which acknowledges the distinctness of public funding and private funding, seeks to provide an integrated view of the funding landscape by combining private and public funding and articulating intervening variables implicated in the funding-performance relationship. As Figure 1 suggests, the startup and working capital of hair salons is a consequence of public and private funding and this means the main conduits of hair salons funding are from public and private institutions. Although both funding sources are presented as equals to the extent that they may both be needed for hair salon performance and sustenance, the access volumes and overall impact may be different as the challenges of smallness distract these firms from borrowing from banks and because the nationality of hair salon owners also complicates their access to finances from public institutions. This makes private small lending, which involves personal saving, borrowing from friends, Matshonisas and private lenders, the most accessible sources of private funding compared to larger public institutions.

Figure 1 also demonstrates that private and public funding are independent variables that shape hair salon performance. As a result, we postulated that the relations between them is complex as it is mediated by intervening variables such as organisational and environmental factors, such as the quality of human resources and recruitment systems, staff 
training and their educational attainments, location, customer care, competition, rent and marketing strategies, and broader environmental variables, such as the external acquisition of technology. The researchers contend that these organisational and environmental ingredients contribute to the conversion of staff's capacities into competencies that drive activity execution, positive energy that oscillate among employees to optimally accomplish tasks and levers that increase overall performance, without which the provision of public and private private funding becomes counter productive. For instance, well qualified and well trained human resources are critical to an organisation's improved productivity in the same way technology acquisition is a critical driver of small business growth. Therefore, the training and development of staff allows SMME personnel to manage or cope with competition, improve the SMME's competitive advantage and overcome market constraints, which collectively impact SMME's growth, profit and productivity.

Figure 1. A proposed conceptual model on the influence of private and public financing, organisational and environmental factors on firm performance (Source: Authors' compilation based on literature).

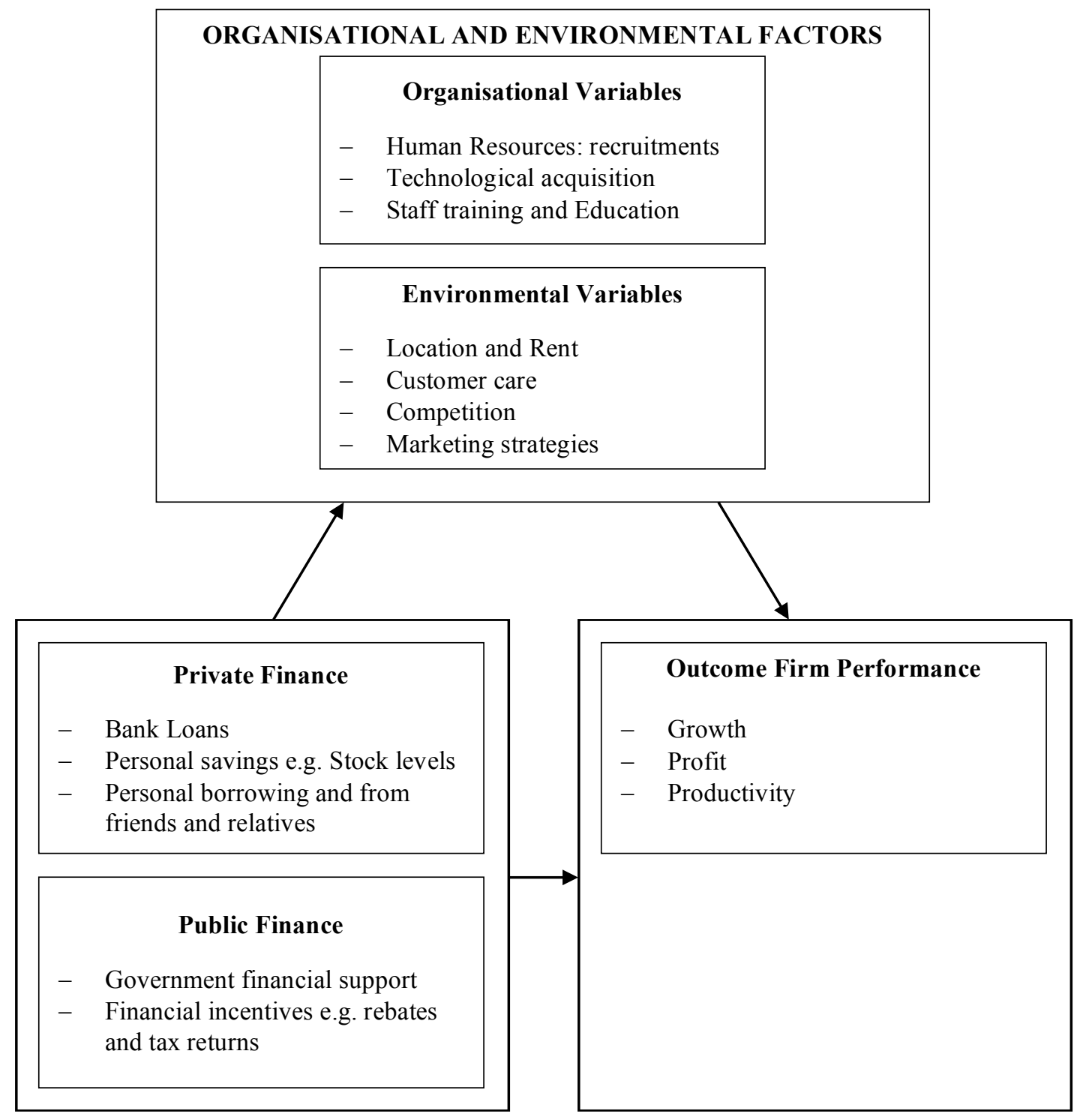




\subsection{Evaluation of Contribution}

Drawing on a large body of extant literature, the current study attempts to breach the polarity in discourses on private and public funding by demonstrating the combinations of private and public funding that offer a hair salon start up and working capital within the South African context. The study contributes to literature on the combinations of public funding (in rare cases funding by subsidiaries of national public funding instutitions) and private (private savings, borrowing from friends and relatives, Stokvels and matshonisas) that give rise to the startup and operations of hair salons. The study also outlines the multiple impediments, such as risk averseness, complicated funding mechanisms and multiple documentations (marketing plans, financial plans, business plans, financial record keeping) that, hinder private banks and public national schemes from funding the small and predominantly foreign-owned hair salons.

The study also demonstrates that there are other intervening variables other than private and public funding that mediate the performance of small businesses, such as hair salons. These variables include internal organisational factors, external acquisition of technology and environmental factors. The study however, argues that the influence of these factors is informed by the size, scale of operations, location and rent, market base of the enterprise, and competition, without which these factors become ineffective in shaping a successful venture expansion and sustenance.

The study also indicates, in consistence with the Perking Theory, that private financing is more accessible and does not have excessive negative externalities, such as high interest on borrowing, complicated re-payment plans, negative consequences such as blacklisting and apprehension for defaulting on payments, in comparison to public funding, which tends to be inaccessible and involves exhorbitant interests charges on the funds borrowed by foreign-owned firms, especially those who do not have permanent residence status. Private financing tends to be desirable when coming from generous relatives and friends who can extend additional loans before previous loans lended are paid in full, for they have no interest payment and have negotiable re-payment plans. If the private funder has business expereince, they may also provide after services such as business modelling, free consultancy services and and advice.

Government subsidiaries and government supported lending insttutions may draw on this model to make informed policy decisions on micro/lending to small businesses. From a practical point of view, SMMEs may consider this article as a rich information source for accessing proven funding sources and use its ideas as a basis for comparability. This article also concurs with the Perking Order Theory's view that different combinations of funding are consequences of asymmetrical information, but however, it can be a logical point for departure for business owners not to consider the trade offs of different funding mechanisms and allowing them to prudently select those risks and opportunities to internalise and externalise. Finally, it is evident that, athough, public funding sources are taxing to foreign-owned businesses, they tend to give lumpsums of money compared to private ones, hence the need to consider combinations of private and public funding.

Lastly the paper article contributes to the development of an integrated model that acknowledges both the centrality of funding and role of intervening variables in shaping venture performance. Our intuition is that this model is fluid, transactive and organic in orientation-allowing for the porosity of boundaries between relationships, and the mutual and bi-directional influence of some variables on each other, as well as the increasing of the intensity of relationships to expand as the business grows.

\subsection{Implications for Further Research}

In view of an array of factors that shape hair salon performance, future studies should examine how other environmental factors, such as size of operations, size of industry clientele base, locational advantages and market base, affect the performance of hair salons, even though their influence could be weaker due to the informality of most of hair salons. Future studies may also consider a comparative perspective of the performance and lacunas of foreign/immigrant-owned and indigenous-owned firms in developing countries contexts. Other studies may also consider mechanisms of improving funding for foreign immigrant businesses as they are critical vehicles for economic growth, job creation and poverty reduction. 


\section{CONCLUSION}

The study considered with great concern the ambiguity in literature on SMME financing that seems to either generalize about public and private funding without differentiating their impact on performance of small firms or assume that funding can be generated from the private or public domain without considering the various combinations of funding from both domains. The reviewed literature cautioned about literature that emphasised the "financial problem" exclusively, thus eliding the influence of organisational and environmental variables that shape SMME performance as if the SMME financing operates in a vacuum in emerging economies. In view of these gaps in literature, we draw on hair salons as a perfect case study that drew on combinations of private and public funding sources, and whose relationship with performance is mediated by both organisational and environmental factors.

Finally, the study developed an integrated conceptual framework on SMME performance that is based on a combination of private and public funding and mediating variables. Although this model is yet to be tested, it is postulated that it is able to explain the complicated growth strategies and conditions of SMMEs in developing countries as it is founded on a systematic review of literature in emerging economy contexts.

\section{AUTHOR INFORMATION}

Dr. Patient Rambe, a holder of a PhD in Educational Technology from the University of Cape Town, South Africa, is a Senior Researcher in the Department of Business Support Studies and the Convener of the Masters and Doctoral Programme Stream at the Central University of Technology in South Africa. He previously served as a Postdoctoral Research Fellow and Assistant Director in the Office of International Academic Projects at the University of the Free State, South Africa. His recent co-authored book is entitled: Leveraging Educational Quality in Southern African educational systems: A practitioners' perspective. Email: prambe@cut.ac.za

Miss Nosiphiwe Mpiti is a Masters of Business Administration candidate at the Central University of Technology in South Africa. Her current research focuses on the influence of private and public finance on the performance of Small scale, micro and medium enterprises (SMMEs). Email: nmpiti@cut.ac.za

\section{REFERENCES}

Afcha, S. (2012). Analyzing the Interaction between R\&D Subsidies and Firm's Innovation Strategy, Journal of Technology Management and Innovation, 7(3): 57-70.

Agbobli, E. (2013). The influence of entrepreneurial and market orientations on small agricultural enterprises in the Vryburg region, $\mathrm{PhD}$ Thesis, Central University of Technology, Free State.

African Response. (2012). Stokvels - A Hidden Economy Unpacking the potential of South African traditional saving schemes. Accessed from http://www.africanresponse.co.za/PressReleases/Documents/2012StokvelHiddenEconomy.pdf

Alasadi, R. \& Abdelrahim, A., (2007). Critical analysis and modelling of small business performance (Case Study: Syria). Journal of Asia Entrepreneurship and Sustainability, 3(2): 1-131.

Agwa-Ejon, J. \& Mbohwa, C. (2015). Financial challenges faced by SMMES in Gauteng South Afric. International Association for Management of Technology IAMOT 2015 Conference Proceedings, (pp. 520-534).

Bank Seta. (2013). The Microfinance Review 2013-“From Microfinance to Financial Inclusion. A review of the South African microfinance sector Trends, successes, challenges and policy issues. University of Pretoria.

Barnard, S. Kritzinger, B. \& Krüge, J. (2011). Location Decision Strategies for Improving Smme Business Performance. Accessed from http://www.actacommercii.co.za/index.php/acta/article/viewFile/156/156. [Accessed 14/06/2016]

Beck, T. \& Demirguc-Kunt, A. (2006). Small and medium-size enterprises: Access to finance as a growth constraint, Journal of Banking and Finance, 30(11), 2931-2943.

Booyens, I. (2011). Are small, medium-and micro-sizes enterprises engines of Innovation? The reality in South Africa, Science and Public Policy, 38(1), 67-78.

Bromideh, A.A. (2011). The widespread challenges of NGOs in developing countries: Case studies from Iran, International NGO Journal,6 (9): 197-202.

Calvin, B \& Coetzee G. (2010), Review of the South African Microfinance Sector Volume II Section IV: Special Products. University of Pretoria - Centre for Micro Finance. Accessed from http://web.up.ac.za/sitefiles/file/1/3841/Volume\%20II\%20Section\%20IV\%20Special\%20Products. Pdf

Copyright by author(s); $\underline{\text { CC-BY }}$ 
Cecchetti, S. G. \& Kharroubi, E. (2012). Reassessing the impact of finance on growth (No.381). Bank for International Settlements.

Centre for the study of social policy. (2007). Customer satisfaction improving quality and access to services and supports in vulnerable neighborhoods. Accessed from http://www.cssp.org/publications/constituents-co-invested-inchange/customer-satisfaction/customer-satisfaction-framework-improving-quality-and-access-to-services-andsupports-in-vulnerable-neighborhoods.pdf.

Chandra, V., Moorty, L., Nganou, J., Rajaratnam, B. \& Schaefer, K. (2001). Constraints to Growth and Employment in South Africa: Evidence from the Small, Medium and Micro Enterprise firm survey, Report No.2: The World Bank Southern AFRICA Informal Discussion Papers.

City of Johannesburg Metropolitan Municipality Public Health By-laws. (2004). Published in Provincial Gazette Extraordinary No 179 Dated 21 May 2004 (Under Notice No. 830).

Cohen, M. \& Nelson, C. (2011). Financial Literacy: A Step for Clients towards Financial Inclusion, 2011 Global Microcredit Summit Commissioned Workshop Paper, Valladolid, Spain. November 14-17, 2011.

Consultative Group to Assist the Poor (CGAP). (2012). A Guide to Regulation and Supervision of Microfinance. Accessed from http://www.cgap.org/sites/default/files/Consensus-Guideline-A-Guide-to-Regulation-and-Supervision-ofMicrofinance-Oct-2012_0.pdf.

Dabale, W.P., Jagero, N. \& Nyauchi, M. (2014), The Relationship between Training and Employee Performance: The Case of Mutare City Council, Zimbabwe, International Journal of Human Resource Studies, 4(4), 61-72.

Davies, R. \& Thurlow, J. (2009). Formal-Informal Linkages and Unemployment in South Africa. Human Sciences Research Council.

Demacon Market Studies. (2010), Chapter Twelve: Impact of Township Shopping Centres on local businesses and informal trade. July, 2010.

David, N. \& Luiz. (2015). The Devolution of the Human Resources Function in South African Multinational Companies, The International Journal of Human Resource Management: 1-23.

Dieden, S. (2007). The SME boom in rural South Africa links to electricity and telephony. Paper to be presented at the Nordic Conference in Development Economics, Copenhagen 18-19 June 2007.

Dzansi, D.Y. and Amoakoh, E. (2014). Does Marketing Research Really Matter for Smaller Businesses Under Competition? A Case Study of Hair Salons in Dr. Ruth S Mompati District, South Africa, Journal of Economics, 5(1): 7-16.

Environmental Finance Center. (2007). Polution Prevention Grant Final Report June 30. P2 and African-American Hair Salon, California State University.

Fafchamps, M. \& Schundeln, M. (2013). Local financial development and firm performance: Evidence from Morocco, Journal of Development Economics, 103, 15-16.

Farooq, M. \& Khan, M.A. (2011). Impact of Training and Feedback on Employee Performance, Far East Research Centre, 5(1), 23-33.

Fatoki, O. (2014). The Financing Options for New Small and Medium Enterprises in South Africa. Mediterranean Journal of Social Sciences, 5(20): 120-127.

Fatoki, O. \& Garwe, D. (2010). Obstacles to the growth of new SMEs in South Africa: A principal component analysis approach, African Journal of Business Management, 4(5): 729-738.

Fredericks, N. (2014). Women in business: Meet network's leading lady, Small Business Connect, August 2014.

Freeman, N. (2015). Financing Small and Medium Sized Enterprises for Sustainable Development: A View from the Asia-Pacific Region. Draft discussion paper submitted to AsiaPacific High-Level Consultation on Financing for Development meeting, Jakarta, Indonesia, 29-30 April. Accessed from www.unescap.org/events/hlcffd2015.

Harash, E., Al-Tamimi, K. \& Al-Timimi, S. (2014). The Relationship between Government Policy and Financial Performance: A Study on the SMEs in Iraq, Journal China-USA Business Review, 13(4), 290-295.

Imran, M., Maqbool, N. \& Shafique, H. (2014). Impact of Technological Advancement on Employee Performance in Banking Sector, International Journal of Human Resource Studies, 4(1), 57-70.

Invested Development (ID). (2012). The benefits of Informal Savings Groups. Accessed from http://investeddevelopment.com/blog/2012/04/the-benefits-of-informal-savings-groups/.

Irving, M. (2005). Informal Savings Groups In South Africa: Investing In Social Capital. Accessed from http://www.cssr.uct.ac.za/sites/cssr.uct.ac.za/files/pubs/wp112.pdf

Ipsos. (2014). Press Release Latest stats on stokvels released. Accessed from http://pressoffice.mg.co.za/ipsos/PressRelease.php?StoryID=248956

Jacobs, E. (2011). Executive brief: Differences in employee turnover across key industries. The SHRM and Management Sciences Journals, 4: 1-11 Accessed 24 January 2015, from http://www.shrm.org/research/benchmarks/documents/assessing\%20employee\%20turnover_final.pdf.

Jiang, J., Zhiming, L. \& Chanyan, L. (2014). Financing Difficulties of SMEs from Its Financing Sources in China, Journal of Service Science and Management, 7: 196-200. 
Johannsmeier, C. (2007). The Social and Economic Effects of the Disability Grant for People with Disabilities and their Households - A Qualitative Study in KwaZulu Natal Province. Accessed from http://opendocs.ids.ac.uk/opendocs/bitstream/handle/123456789/1735/RR\%2074.pdf?sequence=1.

Kareem, S.A. \& Krishnan, O.C. (2011). Public finance VI Semester Core Course BA Economics, accessed from http://www.universityofcalicut.info/SDE/BA_eonomics_I_em_ublic_Finance.pdf.

Katou, A. \& Budhwar, P. (2006). The effect of human resource system on organization performance: Test of a mediating model, International Journal of Human Resource Management, 17(7), 1223-1253.

Katou, A. \& Budhwar, S. (2010). Causal relationship between HRM practices and organisational performance: Evidence from the Greek manufacturing sector, European Management Journal, 28, 25-39.

Kotey, B. \& Slade, P. (2005). Formal human resource management practices in small growing firms, Journal of Small Business Management, 43, 16-40.

Kouser, R., Bano, T., Azeem, M. \& Hassan, M. (2012). Inter-Relationship between Profitability, Growth and Size: A Case of Non-Financial Companies from Pakistan, Pakistan Journal of Commerce Social Science, 6(2): 405-419.

Kwaning, C.O., Nyantakyi, K. \& Kyereh, B. (2015). The challenges behind SMEs' access to debts financing in the Ghanaian financial market, International Journal of Small Business and Entrepreneurship Research, 3(2): 16-30.

Linnan, L., D’Angelo, H. \& Harrington, C. (2014). Literature Synthesis of Health Promotion Research in Salons and Barbershops, American Journal of Preventive Medicine, 47(1), 77-85.

Laosirihongthong, T., Prajogo, D.I. \& Adebanjo, D. (2014). The relationships between firm's strategy, resources and innovation performance: resources-based view perspective, Journal of production planning and control, 25(15), 1231-1236.

Mahapatro, B.B. (2010). Human Resource Management. New Dehli, New Age: International Publishers.

Mahasi, J., Awino, Z.B., Pokhariyal, G.P. \& Ombaka, B. (2013). The influence of external stakeholders and expansion strategies on the relationship between organisational resources and firm performance, Journal of Emerging Trends in Economics and Management Sciences (JETEMS), 4(5), 449-459.

Maurel, C. (2008). Financial Approach to Export Performance in French Wine SMES, In 4th International Conference of the Academy of Wine Business Research, Siena, 17-19 July.

Mohutsiwa, M. (2012). Strategic entrepreneurship and performance of small and medium enterprises in South Africa. Johannesburg: University of Witwatersrand (Unpublished Masters Dissertation).

Mmari, G.A. (2015). Factors influencing performance of women owned small food business and hair dressing salon enterprises in moshi municipality, European Journal of Business Management, 2(3):1-14.

Mortara, L. \& Ford, S. (2012). A guided approach to technology acquisition and protection decisions. Accessed from www.ifm.eng.cam.ac.uk/uploads/Resources/Reports/technology_acquisitions.pdf

Mutezo, A.T. (2005). Obstacles in the SMME finance: An empirical perspective on Tshwane, Pretoria. Masters Dissertation. University of South Africa.

National Credit Regulator. (2011). Literature review on small and medium enterprises' access to credit and support in South Africa. National Credit Regulator, Pretoria, South Africa. Accessed from http://www.ncr.org.za/pdfs/Literature\%20Review\%20on\%20SME\%20Access $\% 20$ to\%20Credit $\% 20$ in $\% 20$ South $\% 20$ Africa_Final\%20Report_NCR_Dec\%202011.pdf[Accessed 05/05/2015].

Naude, D. (2007). The degree of organizational performance measurement in SMEs. A focus on ICT enterprises. Unpublished Dissertation. Unisa.

Nawai, N. \& Shariff, M.N. (2010). Determinants of Repayment Performance in Microcredit Programs: A Review of Literature, International Journal of Business and Social Science, 1(2), 152-161.

Ndofirepi, T. (2016). The impact of Technological Creativity and Entrepreneurship Education on the Entrepreneurship Intentions of Tertiary students in Zimbabwe and South Africa, PhD Thesis, Central University of Technology

Niresh, J.A. \& Velnampy, T. (2014). Firm Size and Profitability: A Study of Listed Manufacturing Firms in Sri Lanka, International Journal of Business and Management, 9(4): 57-64.

Noor, M., Shariff, M. \& Peou, C. (2008). The relationship of entrepreneurial values, firm financing and the management and growth performance of small-medium enterprises in Cambodia, Problems and Perspectives in Management, 6(4), 5564.

Ntsika Enterprise Promotion Agency. (2002). The state of small business in South Africa, 2001 annual review, Pretoria: DTI.

Ojokuku, R.M., Sajuyigbe, A.S. \& Ogunwoye, A.B. (2014). Human resource management practices and small scale business performance: Evidence from Osun state, South Western Nigeria, Journal of Emerging Trends in Economics and Management Sciences, 5(7), 1-6.

Oni, E. \& Daniya, A. (2012). Development of Small and Medium Scale Enterprises: The role of Government and other Financial Institutions, Arabian Journal of Business and Management Review, 1(7), 16-29.

Onsongo, S. \& Muturi, W. (2015). Factors influencing the growth of hair salon enterprises in Kenya: A survey of hair salon enterprises in Kisii Town, IOSR Journal of Business and Management, 17(3), 1-15.

Pandula, G. (2011). An empirical investigation of small and medium enterprises' access to bank finance: the case of an emerging economy, ASBBS Annual Conference: Las Vegas, 18(1), (pp. 255-273). 
Perks, S. \& Austin, G. (2013). Exploring Business Growth Aspirations and Strategic Planning of Hair Dressing Salons in South Africa, Review of Integrative Business and Economics Research, 2(1), 319-332.

RAPS. (2015). Hairdressing Environmental Scan 2015. Accessed from http://rapstc.com.au/wpcontent/uploads/2011/12/Hairdressing-Environmental-Scan-2015.pdf. [Accessed 14/06/2016]

Rambe, P., Mupani, H. \& Chipunza, C. (In press). Employee resourcing strategies, competitive advantage and SMMEs performance: Case of South Africa and Zimbabwe, International Journal of Business and Economic Research.

Rambe, P. \& Makhalemele, N. (2015). Relationship Between Managerial Competencies Of Owners /Managers Of Emerging Technology Firms And Business Performance: A Conceptual Framework Of Internet Cafés Performance In South Africa, International Business \& Economics Research Journal, 14(4): 678-691.

Rambe, P., Ndofirepi, T. \& Dzansi, D. (2015). Influence of Entrepreneurial Education and Technological Creativity on Entrepreneurial Intentions of Students in Zimbabwe: A Theoretical Perspective. Proceedings of the 10th European Conference on Innovation and Entrepreneurship University of Genoa Italy (pp. 576-584), 17-18 September 2015.

Rizos, V. (2015). The Circular Economy: Barriers and Opportunities for SMEs. Accessed from https://www.ceps.eu/system/files/WD412\%20GreenEconet\%20SMEs\%20Circular\%20Economy.pdf.

Rogerson, C. M. (2008). Tracking SMME development in South Africa: Issues of Finance, Training and the Regulatory Environment. Urban Forum, 19: 61-81.

Rogerson, C. (2006), Developing SMMEs in peripheral spaces: the experience of Free State province, South Africa, South African Geographical Journal, 88(1), 66-78.

Rose, R.C. \& Kumar, N. (2006). The influence of Organisational and Human Resource Management Strategies on Performance, Performance Improvement, 45(4), 18-24.

Rwigema, H. \& Venter, R. (2004). Advanced entrepreneurship. Oxford University press, Southern Africa.

Sekolanyane, J. (2004). Measurement of service quality of small business in the Vaal area. PhD Thesis, North West University, South Africa.

Shariff, M., Noor; M., Chea, P., \& Juhary, A. (2010). Moderating Effect of Government Policy on Entrepreneurship and Growth Performance of Small-Medium Enterprises in Cambodia, International Journal of Business and Management Science, 3(1), 57-72.

Skinwell Holdings Limited Annual Report (2011). Annual Financial Statements, Skinwell Holdings Limited, Centurion, Gauteng, 1-69.

Sobeková Majková, M., Solík, J.\& Sipko, J. (2014). The Analysis of Chosen Business Obstacles and Problems with the Financing of Young Entrepreneurs in Slovakia, Economics and Sociology, 7(3), 90-103.

Suttapong, K \& Tian, Z. (2012). Performance Benchmarking for Building Best Practice in Small and Medium Enterprises (SMEs), International Journal of Business and Commerce, 1(10): 46-60.

Tengeh, R., Ballard, H. \& Slabbert, A. (2011). Financing the Start-up and Operation of Immigrant-owned Businesses: the path taken by African Immigrants in the Cape Town Metropolitan Area of South Africa. Munich Personal RePEc Archive (MPRA) Paper No. 38405. Cape Peninsula University of Technology.

The International Organization of Securities Commissions. (2014). Market-basedlong-term financing solutions for smes and infrastructure. Accessed from https://www.iosco.org/library/pubdocs/pdf/IOSCOPD452.pdf.

Thusong Service Centre. (2016). The Government Development Communication Initiative: A Response to Democratic Communication and Citizen Participation in South Africa, accessed from http://www.thusong.gov.za/documents/policy_legal/gdc.htm.

Tsai, K. H. \& Wang, J.C. (2008). External technology acquisition and firm performance: A longitudinal study, Journal of Business Venturing, 23, 91-112.

Tvedten, K. Hansen, M., \& Jeppesen, S. (2014). Understanding the rise of African business: In search of business perspectives on African enterprise development. African Journal of Economic and Management Studies, 5(3), 249 - 268.

Van Scotter, J. R. \& Culligan, P. E. (2003). The value of theoretical research and applied research for the hospitality industry, Cornell Hotel and Restaurant Administration Quarterly Journal, 14-27.

Zhenxing, M. \& Zheng, G. (2008). The relationship between financial factors and firm performance: Emperical evidence from U.S. restaurant firm, Journal of Foodservice Business Research, 11(2), 139-142. 